\title{
Long-Term Land-Use Changes in Czechia as a Flood Risk Influencing Factor
}

\author{
BIČÍK, I. ${ }^{1}$, LANGHAMMER, J. ${ }^{2}$, ŠTYCH, P. ${ }^{3}$, KUPKOVÁ, L. ${ }^{3}$ \\ ${ }^{1}$ Charles University in Prague, Faculty of Science, Department of Social Geography \\ and Regional Development \\ ${ }^{2}$ Charles University in Prague, Faculty of Science, Department of Physical Geography \\ and Geoecology \\ ${ }^{3}$ Charles University in Prague, Faculty of Science, Department of Applied Geoinformatics \\ and Cartography
}

\begin{abstract}
The floods that hit Czechia in the past decade posed a considerable threat to the life and property of the country's inhabitants and brought huge losses reaching dozens of billions of Czech crowns (Hladný 2003; Langhammer 2007). Various factors were named in evaluation of the causes of these exceptional floods, besides others, changes in land-use.

The aim of the article is to assess the nature of long-term changes in intensity, nature and spatial structure of land-use in Czechia with respect to their significance for the runoff process, and especially during the occurrence and progress of floods.

The article makes use of LUCC UK Prague database (Bičík et al. 1996, 2003), an extensive geodatabase designed to evaluate spatial land-use development of individual comparable territory units (CTUs - based on the cadastral units), for the years 1845, 1948, 1990 and 2000.

The effect of changes in land-use on the progress and magnitude of floods has been studied by a number of foreign and Czech authors for various geographical conditions. The model studies cited are usually based on evaluation of selected flood events in a limited territory and simulations of land-use change effect, using recent data and methodical scenarios.

However, none of the studies covers the whole country or the majority of its major river basins, and they do not describe long-term changes using real data. In order to perform assessment of long-term spatial-level changes in land use of the whole country, specific data and methodologies are needed.

We applied long term development data of land-use (1845-1948-1990-2000) in four classes (arable land, grassland, built up areas, other areas) and one index (Change index shows share of changed land-use classes from the whole size of territorial unit). These data were summarized on third order of river basins. There was chosen as the most suitable base for land-use change analysis; this order delimits 121 Czech basins with the average size of $734 \mathrm{~km}^{2}$. Some charts show differentiation of changes in all observed classes of land-use and intensity of land-use changes. Results are discussed and compare with cited literature.
\end{abstract}

\section{Introduction}

The floods that hit Czechia in the past decade posed a considerable threat to the life and property of the country's inhabitants and brought huge losses reaching dozens of billions of Czech crowns (Hladný 2003; Langhammer 2007). Various factors were named in evaluation of the causes of these exceptional floods, besides others, changes in land-use, and specifically decrease in forest areas and high share of arable areas.

The aim of the article is to assess the nature of long-term changes in intensity, nature and spatial structure of land-use in Czechia with respect to their significance for the runoff process, and especially during the occurrence and progress of floods. 
Changes in land-use and landscape cover structure, as well as their influence on the runoff process represent important research topics in geographical and environmental studies. The article makes use of LUCC UK Prague database (Bičík et al. 1996, 2003), an extensive geodatabase designed to evaluate spatial land-use development of individual cadastral areas, represented by comparable territory units (CTUs), for the years 1845, 1948, 1990 and 2000.

District-level data from this database were used, for example, to compare the change in land-use in upstream areas with the structure of lowland district areas (Jeleček 1997). Furthermore, assessment of changes in land-use in the Otava river basin was performed on the level of subbasins and their tributaries in order to evaluate the consequences of extreme floods in Czechia in August 2002 (Bičík et al. 2004).

The effect of changes in land-use on the progress and magnitude of floods has been studied by a number of authors for various geographical conditions. Hydrological and hydraulic modelling methods are usually used for spatial-level evaluation of small and medium-sized river basins (Brath et al. 2006; Bronstert 2004; Crooks \& Davies 2001; De Roo et al. 2001; Niehoff et al. 2002; Shi et al. 2007). The effect land-use changes on the progress of floods has also been evaluated in detail for the recent extreme floods in Czechia (Jeníček 2007; Langhammer \& Sitař 2008). The model studies cited are usually based on evaluation of selected flood events in a limited territory and simulations of land-use change effect, using recent data and methodical scenarios.

However, none of the studies covers the whole country or the majority of its major river basins, and they do not describe long-term changes using real data. In order to perform assessment of long-term spatial-level changes in land-use of the whole country, specific data and methodologies are needed.

This article presents an analysis of essential development trends in land-use structure of Czechia since 1845 together with a suggestion of a possible impact of such changes on the runoff process, especially on the origin, progress and consequences of floods.

\section{Sources and Methods}

\subsection{Methodology and Links to Current Research}

Land-use was one of the key topics of geographical research in the 1960s and 1970s. Stamp's successful work in the United Kingdom led to the creation of land-use maps of various scales for a number of national atlases (see Národní atlas ČSSR [National Atlas of the Czechoslovak Socialist Republic] 1967; Uhorczak 1993, 1999; Žigrai 1975; Götz 1970 etc.). At the same time, extraordinary development of detailed land-use mapping took place. Especially Poland excelled in this research domain, both in terms of methodology development and the number of regional studies (Kostrowicki 1965; Biegajlo 1965, 1972, 1973 etc.). This period of, we may say, intense land-use mapping development was perceived as a means of gaining knowledge of the agricultural-production functions of the area. At the end of the 1960s, this interest slackened and the topics mentio- 
ned "moved" into developing countries. This development stage of land-use analysis could be denoted as the description-registration stage with high application ambitions.

The relatively solid position of land-use mapping in geography ended in practice upon the emergence of new techniques - the development of aerial and satellite remote sensing. This type of research made it possible to provide repeated and relatively quick basic, as well as detailed, mapping of large areas of the Earth's surface, something never achieved using terrestrial large-area mapping. However, to use remote sensing methods mapping of parts of small model territories had to be done, in order to come up with primary explanations and a certain feedback of mapping results, or rather images, of this rapidly developing technique. For these reasons, and also in order to create an inventory of natural resources, land-use mapping has maintained its position as one of the methods used in the research of land-use and landscape cover.

At the beginning of the 1990s, new topics appeared in geography, focused on rural landscape, especially the need of economic restructuring of rural areas and social and environmental restructuring related to it. Previous research topics were included in a broader context both in the sense of their qualitative conditioned relations, as well as in the sense of the hierarchy of corresponding territorial structures. Questions arouse: how and why some rural areas attract people; what is the age, social and ethnic structure in rural communities; should the state intervene in rural areas and how; how to provide protection and reconstruction of environmentally precious territories, etc. These issues contributed to further changes in the already considerably changed (rural) geography because the studied topics had to be related to other issues (natural preconditions for use, environmental risk, optimization of rural settlement, suburbanization, privatization of agriculture in post-socialist countries, etc.). The current (rural) geography therefore deals with a broad spectrum of topics arranged in the following dimensions: general specific, and at the same time, global - partial (local). Its focus incorporates both interaction of nature and society, and factors of objective (potential of development) and subjective development (activities of interest, regulatory measures, etc.).

The basic method we applied in the research of long-term land-use changes consists in dynamic (historical) land-use characterized by the comparison of maps or statistical data based on the maps produced in different periods. It represents one of the few possibilities to analyze acceleration of cultural land-use development. Turner B. L. II (1990) introduced historical-geographical approach in research of global changes of the natural and living environment, and the interaction between the nature and the society within a particular landscape segment. Studies based on projects using remote sensing (Kolár, J.: 1992, 1999 etc.; Feranec, J., Otahel, J.: 1996, 2000, 2001 etc.) can be included in the dynamic land-use category. Studies using balance method that makes use of archived and current data for the last century and a half (Bičík, I. et al.: 1996, 2002 etc.; Jeleček, L.: 1995, etc.) were focused differently. A similar approach was also chosen by the Slovene geographers Gabrovec, M., Kladnik, J., Petek, F.: (1995, 1997 etc.) because Slovenia and Austria dispose of similar archive data as Czechia, allowing for long-term comparison of the surface structure according to the smallest territorial unit - cadastral unit. Himiyama (1994, 1998, 1999, 2000, 2001) developed a specific method that leads to the creation of similar data, only calculated by means of digitizing square maps of various scales and time horizons in Eastern Asia. Besides the methods based on remote sensing and balancing of changes in 
territorial units of various sizes, suitable especially for analyses of larger territorial units, we must point out geo-ecological methods oriented especially at smaller territories due to the demanding nature of field research and further analyses.

At present, the issue of land-use changes is one of the key topics in a number of disciplines, and it encompasses hundreds of papers published in dozens of periodicals. Only a part of them is included here, those whose field of focus makes it possible to evaluate the long-term dynamics of the interaction nature-society from local to state levels.

An extensive, exceptionally detailed and long-term database (LUCC UK Prague) created and used at the Faculty of Natural Sciences of the Charles University forms the foundation for our evaluation. The database uses data on area of individual land-use categories of all cadastral units in Czechia for the years 1845, 1948, 1990 and 2000. These years represent key milestones of Czechia and to a certain extent also Central European, history in the political, social and economic sense (Jeleček 2002; Bičík, Jeleček 2005). The original data had to be adjusted for all the four years in order to ensure territorial and temporal comparability of land-use categories used (Bičík et al. 2001, Bičík and Jeleček 2003 etc.).

There are about 13,000 cadastral units in the Czech Republic. However, some of them changed their area during the past 160 years, some were newly created, some ceased to exist. Therefore, the primary database of cadastral units was "consolidated" into slightly less than 9,000 "comparable territorial units" (CTUs) comparable in size in different periods. The area of almost all thus modified units during the observed more than 160 years has not changed by more than $1 \%$. The average area of thus modified 8,903 BTUs is $8.9 \mathrm{~km}^{2}$.

In individual years, different categorization of land-use was used (for example 1845: 56 categories; 2000: 12), the original data for individual cadastral territories had to be consolidated in order to create a comparable structure. This structure consists of 8 basic categories - arable land (AL), permanent cultures ( $\mathrm{PC}$ - orchards + gardens + vineyards + + hop-fields), meadows (Me), pastures ( $\mathrm{Pa}$, currently registered as permanent grassland - PGL), forests (For), water areas (WA), built-up areas (BuA), and other (O). These basic categories can be "grouped" in various ways; we mostly use three aggregate categories - agricultural land (AgL: $\mathrm{AL}+\mathrm{PC}+\mathrm{Me}+\mathrm{Pa})$, forest areas (FA) and remaining areas $(\mathrm{RA}: \mathrm{WA}+\mathrm{BuA}+\mathrm{O})$. In essence, this simplification provides temporal comparability of data for the entire period observed.

These modifications made it possible to obtain a data set of 8,903 CTUs for each year, 1845, 1948, 1990 and 2000, of the given dimension of eight area categories, fully comparable in terms of time and territory. Other characteristics were added to this database providing complementary information about the CTUs (average altitude, inclination official price of agricultural land, rate of exposure, etc.).

This article does not make it possible to apply all the methods used to evaluate land-use changes using this database. We therefore limited ourselves to a comparison of the development in share of selected categories and a calculation of a change index between 1845 and 2000 (the year 1845 denotes an aggregate set of data obtained for individual cadastral units in Czechia by cadastral mapping throughout 1826-1843). 
Two basic methods were used. The first one was used to evaluate the percentage changes of the share of selected categories (AL, PGL, Fo, BuA and O) between 1845 and 2000. This means that we evaluated categories with the largest area share in most CTUs and, at the same time, with the most significant changes in the share. Such a selection of categories also makes it possible to evaluate the potential influence on the rainfall-runoff situation. Furthermore, overall changes were evaluated, both in terms of prevailing trends of the overall land-use structure, and in terms of the change index. The change index has been introduced and used in numerous papers (Bičík et al. 1994, 2004, 2005 etc.). The indicator reflects the intensity of land-use changes irrespective of the direction of global changes. It evaluates the total percentage of area (out of the CTU total area) where change in land-use occurred between the two years mentioned, based on balance comparison of the initial and final year.

\subsection{Effect of Land-Use Changes on Flood Risk}

Changes in land-use structure have a significant impact on the runoff process throughout its various phases. They may also affect the progress of extreme events (Vilímek and Langhammer 2003). The functional use of the area, the character, intensity and dynamics of changes and the spatial structure of the cover play an important role in the impact on the runoff process (Maidment 1993). The importance of land-use changes differs according to the physical-geographical nature of the land, the intensity of its anthropogenic transformation, the spatial measure of evaluation, and the extremity of the particular rainfall-runoff event (Langhammer 2007).

The most significant processes influencing the runoff process include:

- Intensive agriculture

- Urbanization and industrialization

- Deforestation

- Changes in the quality of vegetation cover

- Changes in the structure of landscape elements

Intensive agriculture as a factor influencing the runoff process is usually connected with the $20^{\text {th }}$ century; nevertheless, significant interventions in land structure and function by agriculture are of long-term nature.

The change from original natural land elements - meadows, pastures and forests, to intensively used agricultural areas is manifested especially by a loss of retention capacity of the soil and by a change in the conditions for forming of surface runoff. There are substantial differences in the retention capacity of agricultural land and forest land or natural meadows, and it affects the capacity of the land to transform flood wave (Kliment and Matoušková 2006; Naef et al. 2002).

Moreover, intensive agriculture is often accompanied by areal drainage of the land, which can accelerate runoff, influence insufficient use of retention capacity, and change the timing of flood waves, especially in the case of open drains.

In terms of effect on the runoff process, there are two main forms of dewatering, acting in different ways.

Open drains concentrate surface runoff and accelerate water drainage from the land without making use of its retention potential. This leads to an increase in the steepness 
of the flood wave, increase in culmination flows in downstream areas, changes in flood wave timing, and reduction of the transformation effect of the land on the flood runoff (Maidment 1993).

On the other hand, closed drains have a positive effect on runoff by increasing water infiltration in the soil, thus reducing surface runoff and, at the same time, creating retention spaces above the drains bigger than those that can be created by non-dewatered soil. This results in a more efficient transformation of the flood wave, reduction of the culmination flow and distribution of the flood wave over time. As a rule, runoff culmination from drains occurs with a delay compared to culmination in the recipient; however, at the same time, it precedes culmination from surface and underground runoff of non-dewatered areas. The mechanism of action is limited by the infiltration capacity of the soil, and when exceeded, the drain ceases to have an effect on the runoff (Doležal 2005; Wiskow and van der Ploeg 2003).

Closed drains have, the highest effect during small floods, as well as during the initial phases of large floods, when more efficient transformation of the surface runoff leads at least to a partial reduction in the culmination flow. During extreme floods, when the design capacity of the drain is exceeded, there is a danger of its overload and destruction, together with considerable erosion and material damage. Currently, it is believed that the overall effect of drains on flood runoff is significantly lower than generally supposed. (Hladný et al. 1998) state that during floods in Moravia in 1997 analyses showed that drain runoff contributed to culmination with $2-5 \%$.

Urbanization and industrialization of landscape represent the most intensive form of transformation of original natural structures that have an effect on the runoff process. Thanks to surface reinforcement, urbanized areas show virtually no retention capacity; to the sewerage system also accelerates surface water runoff.

Moreover, industrialized areas and especially areas with surface mining are frequently accompanied by displacement of water courses, sewerage or even excessive piping in river beds, transfer of water between basins, intensive drawing on water sources and their purpose-oriented accumulation. Uncovered areas acquitted of vegetation, as well as original hydrographic network then lack the ability to retain water, and therefore, flood protection has to rely on technical solutions. During extreme events the limits of protective elements are exceeded and enormous damage is inflicted on property and infrastructure.

Deforestation, or the share of forests within a river basin and its temporal-spatial changes are traditionally perceived as a very significant element that affects the nature of the rainfall-runoff process (De Roo et al. 2001; Maidment 1993). Forests have a positive effect on water retention in the river basin, transformation of the flood wave and its distribution over time and related reduction of culmination flow and effect on the concurrence of runoff waves from subbasins. The transformation function of forests differs according to their species composition, age, growth and health, and the nature of forestry. An important role is also played by geographical characteristics - the nature of the relief, hydrographic networks, the total forest percentage, and spatial distribution of causal rainfalls. Deforestation 
in the area of flood wave formation, i.e. in mountane regions and, generally, in headwater areas, where vegetation interception plays a crucial role in the rainfallrunoff process, has the greatest effect on the course of the flood (Robinson et al. 2003).

Besides the physical presence or absence of the forest, the nature of forestry is a very significant factor influencing runoff during floods. Building of reinforced forest roads used by heavy machinery contributes, especially in sloped terrains, to intensive concentration of surface runoff, and during heavy rains secondary hydrographic network is created, which leads water away from the forest much faster than in areas with less intensive cultivation.

Besides spatial distribution of landscape elements, qualitative condition of vegetation, especially of forest covers, significantly affects the runoff process. Influence of the health condition of the forest on the runoff process plays an important role especially in headwater regions where runoff is formed. Results of experimental works (Krovák et al. 2004) point especially at the impact on the balance in the runoff situation. In addition to a direct effect of deforestation on the change in the runoff situation, changes in the quality of the forest stand are also reflected in impact on temperature-humidity landscape properties, reflected in changes in microclimatic characteristics (Hais 2006). Areas with impaired vegetation cover show surface overheating, and subsequently, considerable heating of air; heated air can take in greater volume of water in the form of vapour. Sudden cooling may then lead to torrential rains, with subsequent development of floods (Trenberth 1999).

Spatial structure of the landscape cover also has a significant importance in surface runoff formation, and the nature and timing of its progress. In the $20^{\text {th }}$ century, extensive consolidation of agricultural land occurred in the majority of developed countries, motivated by the effort to achieve better agricultural efficiency, higher yields and production profits.

This process caused a disintegration of the mosaic-like landscape arrangement and its transformation into extensive groups of large fields with monocultural crops. This change brought a possibility of a faster runoff due to the land removal of obstructions and natural retarding bands originally separating land. Changes in the land cover structure affect especially the speed and timing of surface runoff and the transformational capacity of the basin. Analyses using hydrological modelling showed that even a small intervention in the conditions and structure of individual land types or agricultural crops may cause considerable fluctuation of runoff conditions (Podhrazska 2002).

The impact of functional use of the land, the land cover structure, and its vegetation quality on the runoff process is limited by the total retention capacity of the landscape. Upon exceeding the infiltration capacity of the land and retention capacity of the territory, the given land-use element ceases to play a significant role in the runoff process. The limit for such a change to occur depends on the physicalgeographical conditions of the territory, as well as on the nature and intensity of its use; however, it usually does not exceed the level of 5-10 years rainfalls (Langhammer 2007). 


\subsection{Information Resources for Evaluation of Land-Use Changes}

The choice of information resources is of key importance for the interpretation of land-use changes that influence the runoff process. These resources have to correspond to the purpose of the evaluation and offer accuracy adequate to the type of analysis used. The term accuracy incorporates several qualitative aspects of data distinction:

- Spatial accuracy;

- Temporal distinction;

- Level of detail in division of land-use categories.

Table 1 - Relationship between spatial accuracy, distinction of functional categories and data use and landuse

\begin{tabular}{|c|c|c|c|c|c|c|}
\hline Scale & $\begin{array}{l}\text { Spatial } \\
\text { resolution } \\
\text { of elements }\end{array}$ & $\begin{array}{l}\text { Typical } \\
\text { evaluation } \\
\text { level }\end{array}$ & $\begin{array}{l}\text { Data } \\
\text { resource- } \\
\text { Examples }\end{array}$ & $\begin{array}{c}\text { Time } \\
\text { distinction }\end{array}$ & $\begin{array}{c}\text { Landuse } \\
\text { categories } \\
\text { segmentation }\end{array}$ & Use \\
\hline Micro & $10^{-1}-10^{2} \mathrm{~m}^{2}$ & $\begin{array}{l}\begin{array}{l}\text { Individual } \\
\text { objects }\end{array} \\
\end{array}$ & $\begin{array}{l}\begin{array}{l}\text { Terrain } \\
\text { mapping }\end{array} \\
\text { Aerial scans } \\
\text { LPIS } \\
\begin{array}{l}\text { Forestry } \\
\text { maps }\end{array}\end{array}$ & $\begin{array}{l}\text { High } \\
\text { Minimum } \\
\text { Minimum }\end{array}$ & $\begin{array}{l}\text { Detailed } \\
\text { categorization, } \\
\text { possibility of } \\
\text { distinguishing } \\
\text { individual } \\
\text { objects and } \\
\text { their qualitative } \\
\text { characteristics } \\
\text { Limited due to } \\
\text { panchromatic } \\
\text { records } \\
\text { Limited, } \\
\text { distinction } \\
\text { of agricultural } \\
\text { lands only } \\
\text { Limited, } \\
\text { distinction } \\
\text { of agricultural } \\
\text { lands only }\end{array}$ & $\begin{array}{l}\text { Input for detailed } \\
\text { hydrodynamic } \\
\text { modelling on the } \\
\text { level of microfloods } \\
\text { Detailed analysis } \\
\text { of alluvial plain } \\
\text { morphometry } \\
\text { changes }\end{array}$ \\
\hline Meso & $10^{2}-10^{4} \mathrm{~m}^{2}$ & $\begin{array}{l}\text { Homogeneous } \\
\text { areas }\end{array}$ & $\begin{array}{l}\begin{array}{l}\text { Satellite } \\
\text { scans }\end{array} \\
\text { CORINE } \\
\text { landcover } \\
\text { Topographical } \\
\text { maps }\end{array}$ & $\begin{array}{l}\text { Medium } \\
\text { Limited }\end{array}$ & $\begin{array}{l}\text { Detailed } \\
\text { categories of } \\
\text { functional use } \\
\text { of the territory } \\
\text { and landscape } \\
\text { cover } \\
\text { Limited } \\
\text { to basic } \\
\text { categories }\end{array}$ & $\begin{array}{l}\text { Input for hydrological } \\
\text { modelling on the } \\
\text { level of partial basins } \\
\text { Geostatistical } \\
\text { analysis of bonds } \\
\text { between changes } \\
\text { in the landscape } \\
\text { and runoff response } \\
\text { Identification of } \\
\text { critical elements } \\
\text { in the landscape }\end{array}$ \\
\hline Macro & $10^{3}-10^{6} \mathrm{~m}^{2}$ & $\begin{array}{l}\text { Closed } \\
\text { spatial units }\end{array}$ & $\begin{array}{l}\begin{array}{l}\text { Historical } \\
\text { maps }\end{array} \\
\text { LUCC } \\
\text { database } \\
\text { Statistical } \\
\text { data }\end{array}$ & $\begin{array}{l}\text { Very high } \\
\text { Very high } \\
\text { High }\end{array}$ & $\begin{array}{l}\begin{array}{l}\text { Basic } \\
\text { categories } \\
\text { of landuse }\end{array} \\
\text { Basic } \\
\text { categories } \\
\text { of landuse }\end{array}$ & $\begin{array}{l}\text { Statistical evaluation } \\
\text { Typology of } \\
\text { processes of } \\
\text { landscape changes } \\
\text { Identification of } \\
\text { regions showing } \\
\text { critical nature } \\
\text { of changes }\end{array}$ \\
\hline
\end{tabular}


Combination of these aspects delimits the possibilities of using individual data inputs for various types of analyses (Table 1).

Data showing the highest spatial accuracy and, at the same time, offering the highest variability of distinction of functional categories of cover and land-use are provided by purposeful field mapping. However, obtaining the data is time-consuming and demanding financially, it is limited only to the current period, and the quality of the data may be burdened by the subjective nature of the evaluation. Inputs comparable in time and accuracy are presented by aerial imagery; unlike field research it provides data for a relatively long period. For Czechia orthophotographic scans from the end of the 1930s can be used; however, their panchromatic nature poses a limitation for their analysis. Furthermore, specific digital geodatabases can be used for detailed analyses during partial tasks, such as, for example, LPIS (Ministry of Agriculture, 2008) or forest maps (Forest Management Institute, 2008). These databases provide detailed information together with high spatial accuracy. However, their use is limited by the given thematic content and coverage of merely a certain spectrum of landscape elements. As for analyses of the runoff process, they are used on the micro-level of spatial accuracy, usually for calibration and construction of scenarios of hydrodynamic models describing the flow conditions in the floodplain or changes in headwater areas (Horritt and Bates 2002); however, their use for more extensive spatial units has is difficult.

The highest variability of data resources is apparent for medium spatial accuracy, where the dominant position is held by satellite data resources. These resources provide high variability in terms of spatial resolution, the possibilities of distinction of qualitative cover classes, as well as temporal distinction (Jensen 2000). To be used for runoff analysis, they provide quality input data for modelling of the rainfall-runoff process and for evaluation of geo-statistical bonds between anthropogenic changes in the landscape and the runoff process.

On the other hand, for the purpose of analysis and typology of long-term changes in land-use, data covering long periods are suitable as the demands for spatial resolution and detail of land-use segmentation are limited. In this respect, the major role is played by data derived from historical maps of Central Europe, offering sufficient accuracy from the mid-19 ${ }^{\text {th }}$ century (Bičík et al. 2003; Langhammer and Vajskebr 2003; Legesse et al. 2003).

\subsection{Data Resources Used}

For the purposes of this study we had to find an optimum source of spatial division of the country's territory into basins, and a suitable mathematical order level of evaluation. The database DIBAVOD (T. G. Masaryk Water Research Institute, 2008) was chosen as the basic source of hydrological spatial data; this database offers digital thematic layers on hydrography and water management, over the basic map of Czechia $1: 10,000$, including the hydrological division of the basins.

The choice of the spatial level of observation of changes in land-use was chosen taking into account the spatial precision of the database LUCC UK Prague that divides the territory of Czechia into slightly less than 9,000 BTUs, with the average size of 
$8.9 \mathrm{~km}^{2}$. Third order of basins was chosen as the most suitable base for land-use change analysis; this order delimits 121 Czech basins with the average size of $734 \mathrm{~km}^{2}$. As the database LUCC UK Prague draws upon cadastral division, which in the vast majority of cases does not correspond to basin boundaries, inclusion of crossboundary BTUs into individual basins had to be resolved. The following rule was applied: cross-boundary BTUs will come under the basin with geographical centre (centre of gravity) of the BTUs. Except for a few exceptions (especially extremely irregular, oblong polygonal shapes) BTU polygons divided in such a manner come under basins under which their major parts come. The tool "Polygon to Point" was used for this purpose in the ArcGIS software, creating centroids for all the BTUs. Using spatial join of the LUCC UK Prague database and the database of generated centroids all BTUs were aggregated, including their attributes carrying information on their land-use, according to the observed basins. However, as there are big differences between the size of individual basins, and some cross-boundary basins cover our country in only a small part, it had to be decided whether basins with an extremely small number of BTUs should be included in the evaluation. After testing it was decided that basins containing less than 10 BTUs would be excluded from the evaluation. These are frontier basins with marginal size, without exception. All BTUs of the eastern part of the Opava region (the Hlučín region) were also excluded from the evaluation as no land-use data are available for this region for 1845 .

\section{Results}

3.1 Development of Selected Area Categories throughout $1845-2000$ in $3^{\text {rd }}$ Order Basins in Czechia

\subsubsection{Arable Land}

The share of arable land was reduced markedly in Czechia between 1845 and 2000. Increase of the share of arable land in the Czech lands is characteristic for the period until the 1880s; then the share started to decrease, and this trend is most notable in 1945-1961. The total decrease in the share of AL for $1845-2000$ is about $17-18 \%$. At the same time, significant regional differentiation of changes in the share of arable land is characteristic. The highest decrease is confined to the mountains and foothills, as a consequence of economic patterns (differential rent I). This led to large structural changes after the full surge of market agriculture. Naturally, significant decrease in the share of $\mathrm{AL}$ is characteristic for large urban agglomerations and mining areas (especially the North Bohemian Coal Basin and the Ostrava region), manifested especially in the basins of the Bílina, Ohře and Odra, and Ostravice rivers.

Out of the 97 examined basins, 7 basins are characterized by slight increase in the share of arable land (usually up to 10\%) in 1845-2000. Characteristic features of these basins include favourable agro-climatic conditions (Eastern Bohemia and some basins of Moravian valleys). The reason is that in these basins agriculture achieved substantially higher yields than in basins with worse conditions. Therefore, significant landscape adaptations were performed here in the second half of the $19^{\text {th }}$ century, such as desiccation of ponds or the Labe river pools and cut-off meanders (the same happened in Central and Lower Moravia), straightening of water courses, abandoning 
of meadows and pastures. This led to an increase in the share of arable land. Minimum share of forest areas in these regions with intensive farming is also typical.

The greatest decrease in the share of AL relates to people abandoning arable land in the mountains from the Cheb region to the Jablunkov region, i.e. especially upstream with high erosion potential. The main reason for this is the introduction of land rent due to which it was no longer profitable to use the montane land of low quality as arable land, especially at time of inter-regional transport of economically produced food from regions with more favourable agro-climatic conditions. This mechanism initiated a decrease in population in most mountainous areas, accentuated after World War II by the transfer of Czech Germans in some of them. Another area showing great decrease in the share of AL is the Prague agglomeration, defined as the area of the lower Vltava river and its tributaries in the Prague valley. In Sumava (the Bohemian Forest), the Czech Forest and the Novohradské Mountains the share of AL was reduced due to a failure to completely re-settle the rural mountainous areas after the transfer of the Czech Germans, and due to an installation of engineer measures along the western frontier, limiting the possibility to use AL beyond the line and in its vicinity. River basins of the Moravian-Slovak borderland also show a considerable decrease in the share of AL. This decrease is apparently related to the abandonment of the mountains and movement into lower lands and strong industrial cores along this border - the Ostrava and Zlín regions, having a significant effect on the intensity of farming and pastures higher above the sea level, thus contributing to the reduction of AL share.

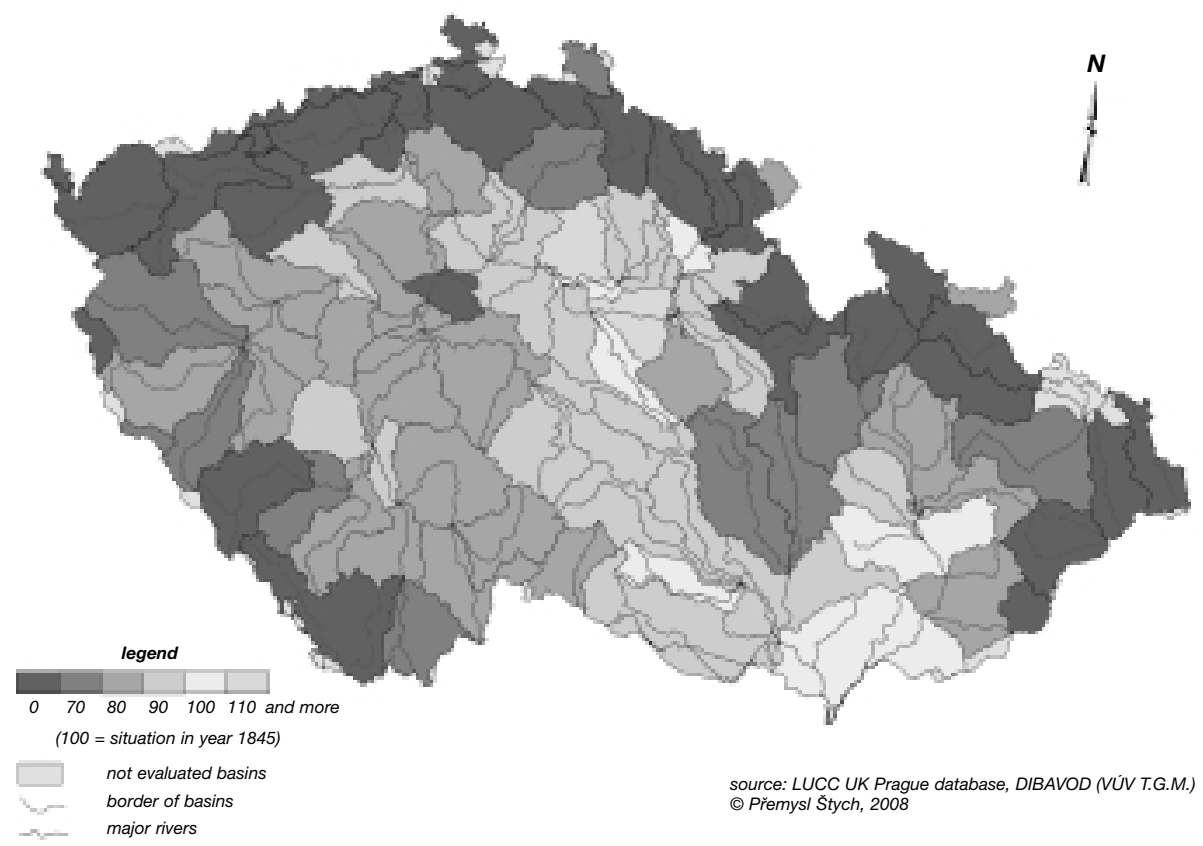

Figure 1: Evolution of share of arable land in major basins of Czechia 


\subsubsection{Permanent Grassland}

The original Land Registry distinguished more categories of meadows and pastures; from January 1, 2002, they are registered as one category of permanent grassland cover (PGL). We joined the meadows and pasture plots for the purpose of this evaluation because in 2000 the then differences in both categories became substantially smaller. The total share of this category in Czechia decreased significantly. Without a doubt, it is related to the fact that production of meadows and pastures, in the past essential for feeding cattle and sheep, lost its original significance due to new technologies based on intensive plant production of feed on arable land. At present (after 1990), the visible increase in their share in Czechia has been caused by reduced intensity of farming and by spontaneous growth on the original arable land.

The increase in the share of PGL reaches its maximum in the northern quarter of Czechia, in peripheral parts, in medium and higher altitudes. Why in this area? This area has seen long-term and strong industrialization bringing sufficient jobs outside the agricultural sector, and therefore, low-quality inclined AL was transformed into PGL. Insufficient population in rural areas in parts of these basins after the transfer of Czech Germans in 1945-1948 also apparently played its role. The trend of increase in the share of PGL should be seen positively from the environmental, landscape and water-management points of view.

The highest decrease in the share of PGL can be traced in Central Bohemia; it has been caused by intensive farming on good-quality land (especially north of Prague), strong urbanization of the Prague agglomeration, especially after 1948, and suburbanization after 1990. Another such area can be found in South Moravian valleys

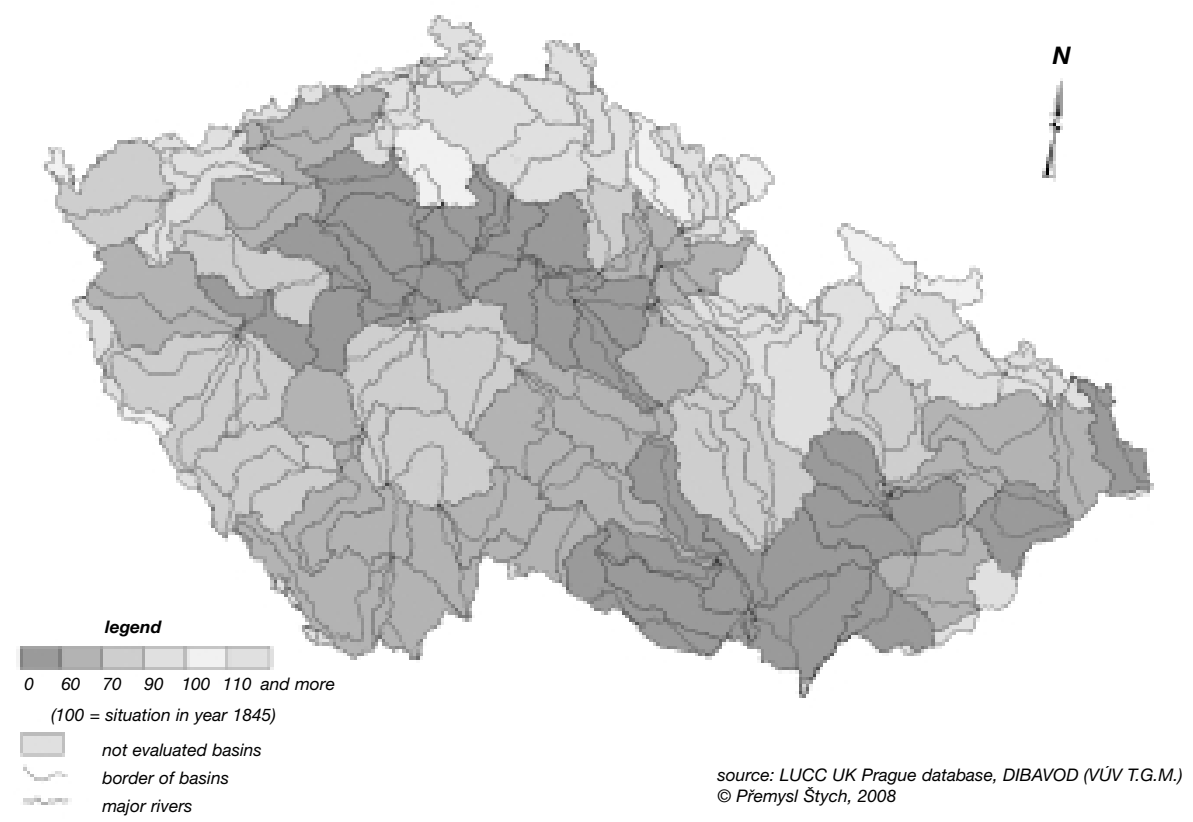

Figure 2: Evolution index of permanent grassland acreage in the main basins of Czechia 
with intensive farming and permanent cultures (vineyards, orchards, and gardens,) on fertile land, obviously brining farmers a more significant economic effect than meadows and pastures.

\subsubsection{Forest Areas}

Evolution of the share of forests in Czechia shows a long-term rising tendency; since the end of the $19^{\text {th }}$ century, the size of this category has risen by $15.6 \%$, mostly in the period 1948-1990. At the same time, it should be noted that forest areas attract the highest degree of criticism of the use of balance statistical data. These areas include not only grown forests but also clearings, forest paths, manipulation areas, devastated forests, but do not include, for example, forests spontaneously grown on AL or PGL or forests in the first zone of NP or military regions. The overall evolution of the share of this category shows considerable inter-regional differences, both in terms of assessment on the CTU level and on the level of larger units, both territorialadministrative (the so called municipalities with extended competence; regions, districts) and units delimited according to natural aspects, such as in this case where units are formed by $4^{\text {th }}$ order basins. The figure shows that several lowland basins (the Labe basin, the Morava basin, the Middle Vltava river and the Kocába river) show a decrease in the share of forest areas (documented by the Land Registry data). This is obviously related to high fertility of Agricultural Land (AgL) and good climatic conditions, which ensure high-effect of agriculture. Moreover, we would like to point out that already in 1845 the share of forest area in these regions was very small.

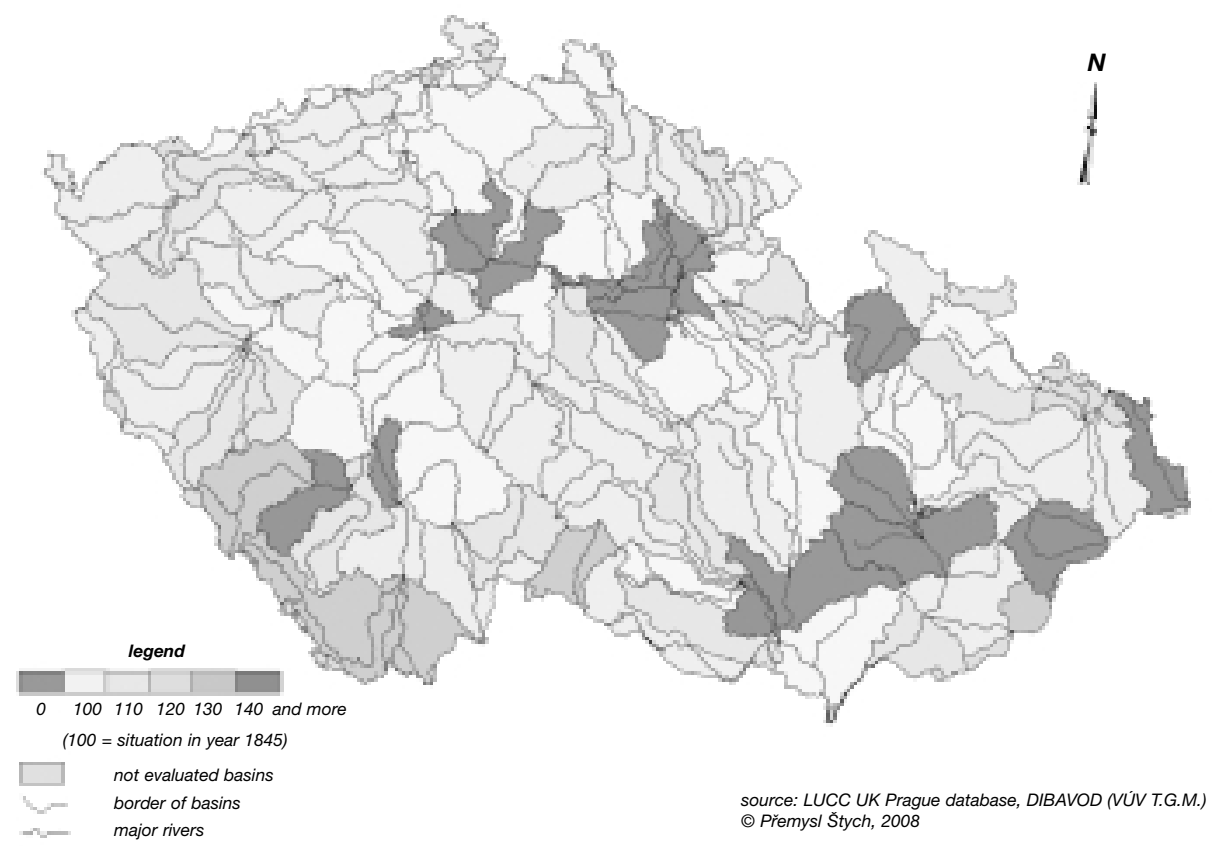

Figure 3: Evolution index of share forest areas in the main basins of Czechia 
Therefore, the actual decrease may only encompass hectares by which the FA size became reduced in these areas.

Increase in the share of forest areas by twenty and more per cent is shown by basins in South-Western and Western Bohemia, along the Moravian and Slovak border and in a part of the Krkonoše Mountains, the Orlické Mountains and the Jeseníky Mountains. Here the increase in the share of forest areas by one fifth and more since 1845 is caused by the abandonment of areas unsuitable for the originally self-supplying agriculture in mountainous areas and foothills, unable to compete with areas with better conditions due to the development of market conditions since the 1880s. Therefore, a part of arable land was transformed into PGL at first, reducing the intensity of agricultural use of the region, and gradually other AL and PGL plots were moved into the forest area category.

\subsubsection{Built-Up Areas}

Built-up areas $(\mathrm{BuA})$ represent the second category with the most significant increase in the period observed (approximately 2.5 times in 1845-2000). Interregional differences are significant as the increase in the share of $\mathrm{BuA}$ is closely related to the urbanization phases over the past two centuries, characterised by a gradual concentration of the urbanization process into the most important core areas. Localization and intensity of the increase in the share of $\mathrm{BuA}$ corresponds considerably to Hampl's concepts of polarization of Czechia. The highest increase is

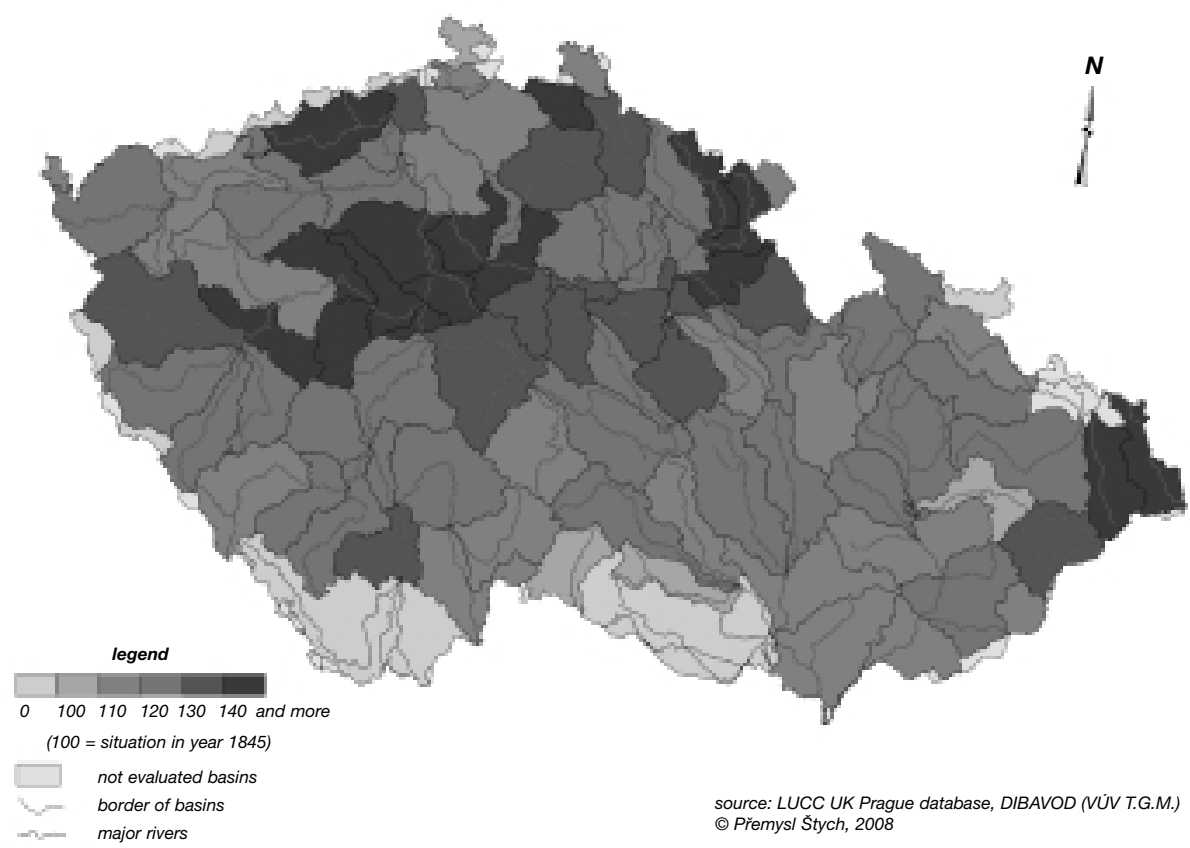

Figure 4: Evolution of the share of built-up areas in the main basins of Czechia 
shown by highly exposed areas of Czechia, representing the main development cores and their background. Most basins show a 2.5-3.5time increase in the share of BuA since 1845 .

The Prague agglomeration shows the maximum increase, with a similarly affected territory band in the direction to the towns of Plzeň and Mladá Boleslav. This area is also characteristic by development of transportation networks, as well as of service and storage premises along main transportation axes in the background of larger cities, especially during after 1990. The Bílina basin is another area with high urbanization, industrialization and strong landscape devastation, accompanied, besides others, by extensive increase in the share of remaining areas $(\mathrm{RA}=\mathrm{BuA}+\mathrm{WA}+\mathrm{O})$. The last similar areas are the Upper Nisa river basin (the Liberec - Jablonec agglomeration) and the area of North-Eastern Bohemia, with a strong first wave of industrialization. The last area showing similar trend is the Ostrava agglomeration, i.e. the basin of the Ostravice, Olše and Odra rivers.

The smallest increase in the share of built-up area can be traced especially in strongly peripheral basins directed towards Germany, as well as Southern Bohemia in the area of the Upper Vltava and Malše rivers, affected by long-term emigration and post-war transfer of Czech Germans. The Southern Moravia and the Osoblažsko regions (Czech Silesia) with the lowest increase in the share of BuA were apparently affected by the transfer of Silesian Germans, as well as by rare migration of Czech inhabitants in the past half-century.

\subsubsection{Remaining Areas}

Remaining areas (RA) represent a category with the most significant growth both in Czechia and in other developed European countries. This category shows broad inner differentiation as it represents a conglomerate of naturally infertile areas (sand dunes, stone fields, rock outcrops, etc.) as well as of areas relatively environmentally precious (cemeteries, bands along transportation lines, etc.), but also special-function zones (military regions, 1st zones of national parks), irrespective of the actual cover of the territory. The share and growth of RA thus does not allow for univocal evaluation. Some land lots included in RA represent environmentally precious places that function as an important shelter of plant and animal species and form the so called new wild (Lipský 2002, 2005 etc.).

Regions with the highest increase in the share of remaining areas represent continuous territories from the town of Cheb to the town of Ustí. This region is characterized by extensive mining, large dumps, high rate of industrialization and extensive building on green areas. Also building and reconstruction of the main and secondary transportation routes, especially in the period of 1948-1990 were realized. Another area with a strong increase in the share of RA is Sumava (the Bohemian Forest) where the high increase was affected by the construction of the iron curtain in the Communist era, and later by the establishment of the Šumava National Park and the delimitation of its conservation zones with strictly limited socio-economic activities. Intensive residential, industrial and service-sector construction represent the motivating factor for the development of RA in Central Bohemia and Eastern Moravia. 


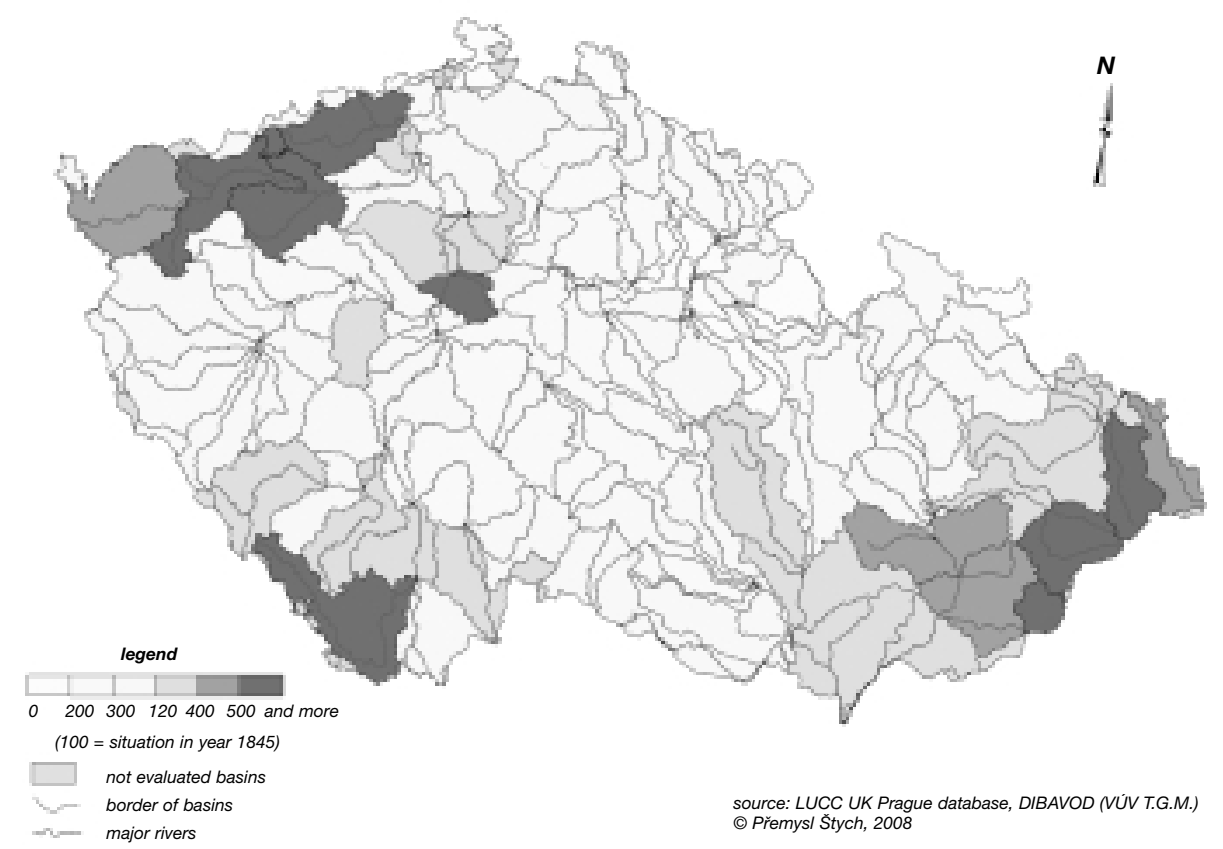

Figure 5: Development of other areas expanse in main basins of the Czech Republic

Minimum growth of remaining areas is shown by the region of Eastern Bohemia, characterized by a high proportion of native inhabitants, and fertile and intensively agriculturally used land. Furthermore, a minimum growth can be seen in the strongly peripheral areas. The only peripheral and strongly depopulated Šluknov region shows a decrease in the share of remaining areas in the given period.

\subsection{Change Index}

The change index (CI) of the observed basins shows higher differentiation than in the case of previously analyzed Czechia regions, although on average the territorial units are only slightly smaller. This shows that unlike districts (administrative regions) basins are more internally homogeneous. For the period observed, the highest change index is shown by the Bečva river basin of the towns of Vsetín and Rožnov, with the CI 38.2 (i.e. $38.2 \%$ of the territory changed land-use category between 1845 and 2000!!). The second highest CI was shown by the Bílina river basin (36.7) and the Lower Vltava river and the Botič brook basins (36.4), an essential part of the Prague agglomeration core.

On the other hand, the lowest change index was shown by the Loučnice river basin (5.6), the Middle reach of the Labe river (6.6) and the Bystrice river (6.8). Relatively high differentiation of the $\mathrm{CI}$ among the basins clearly documents a high degree of difference in the evolution of the land-use. This is apparently related to the fact that 


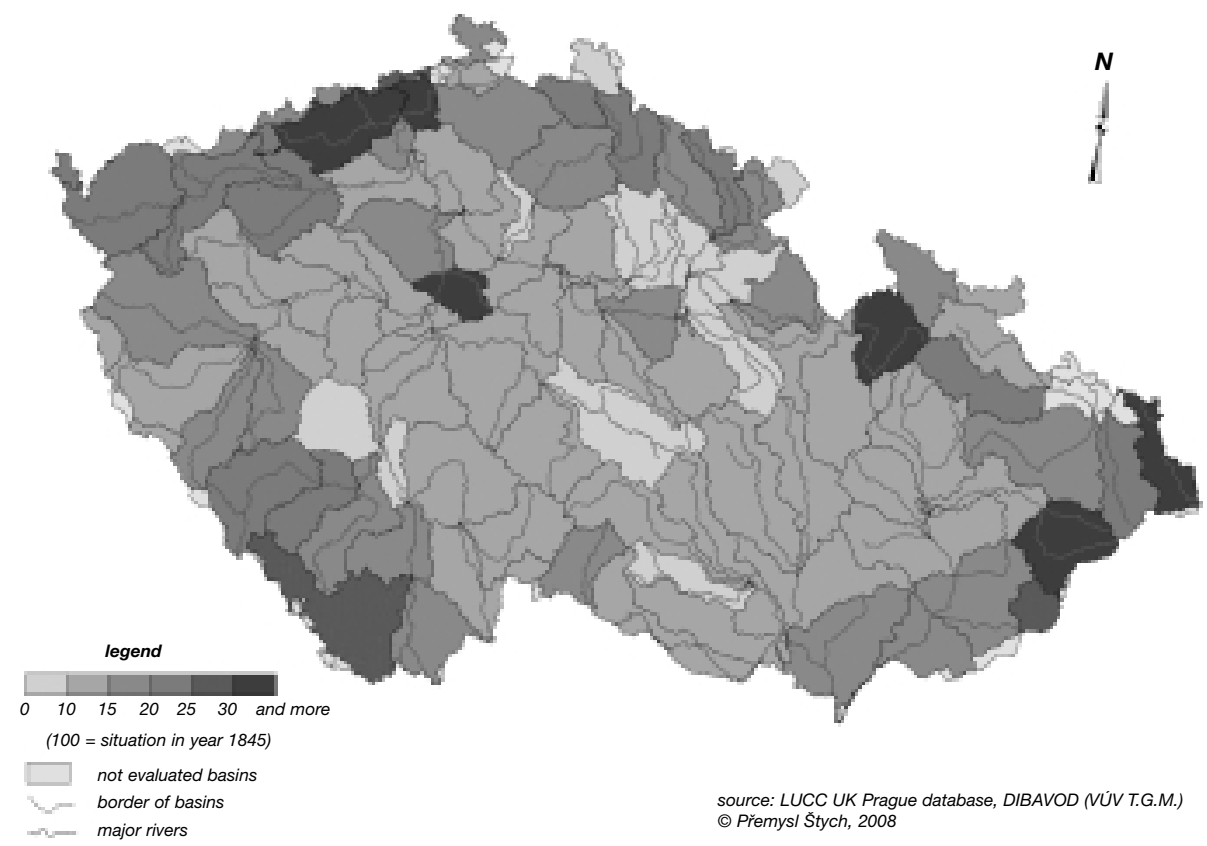

Figure 6: Change index between 1845 and 2000

in the initial year the structure of the areas was clearly related to agriculturalproduction functions, without greater possibilities of transport of agricultural products at longer distances. Therefore, agricultural activities were indispensable even in areas with higher elevation, in less favourable conditions. Urbanization and industrialization gradually led to significant changes in land-use in major settlements. And finally, the transfer of Czech Germans affected the evolution of land-use in the broader frontier band, just like the "iron curtain" construction. Therefore, the differences in the changes in land-use show functional landscape differentiation in individual basins as a result of evolution of the society and developing requirements for specific areas.

\section{Discussion and Conclusions}

The observed period is sufficiently long to evaluate land-use changes for individual basins with the use of balance statistical data. In terms of changes in the society, this period begins with a shift from predominantly self-supply agriculture of closed localities to market orientation and gradual loosening of local reclusiveness. The shift goes through the industrial period with a development of market economy, to the present period of post-industrial society. It is logical that the society assigned different functions to individual parts of landscape, logically reflected in different land-use models. 
Overall, this period is characterized by two different land-use development tendencies. Until the end of the $19^{\text {th }}$ century, slow increase in the share of agricultural land took place. Afterwards, there were gradual decrease and structural changes, more apparent especially in 1948-1990, together with other changes after 1990. In spite of these, to a certain extent, contradictory trends considerable functional differentiation of land-use occurred between 1845-2000. This differentiation is reflected in the land-use changes of individual basins. It is affected by the position of individual basins in terms of natural conditions, but the role of socio-economic conditions expressed e.g. by the degree of socio-economic exposure of individual basins increased markedly.

The general result of land-use changes in Czechia based on balance evaluation of statistical data should be perceived positively from environmental, as well as watermanagement and landscape points of view (increase in the share of forest areas, decrease in the share of arable land). However, the processes taking place in the landscape during the past 160 years are proven by this research only partially, as large regional differences are apparent in land-use evolution in individual basins.

Changes in land-use between 1845 and 2000 can be divided into the following categories, making use of the change index and characteristic processes of the landuse categories observed:

- Relatively stable structure in basins where the category changed due to balance evaluation by $5.6-7.8 \%$. These are especially territories of intensive agricultural use, significantly ploughed up, characteristic for the middle reach of the Labe river I and II $(\mathrm{CI}=6.6$ and 7.2), the Lower Jizera River (7.5). Another group constitutes of basins of medium to weak intensity of agricultural use with a more varied structure and basins with substantial natural limits to agricultural use: basins of the Loučná (5.6), Bystřice (6.8), Stěnava (7.3) and Smědava (7.8) rivers.

- Significant changes in land-use caused by strong urbanization and industrialization, characterized by strong decrease in the share of $\mathrm{AL}$ and $\mathrm{AgL}$ and increase in the share of $\mathrm{BuA}$ and $\mathrm{RA}$ areas, accompanied by a relatively high $\mathrm{CI}$ degree and with relatively big differences of CI among individual CTUs of the given basin: the Lower Vltava river with the Botič brook (36.4), the Lower Vltava river (27.2), the Lower Orlice river.

- The position of strongly industrialized basins is somewhat different; considerable decrease in the share of AgL occurred here at the same time due to the transfer of Czech Germans after WW II (1945-1947), and subsequent failure to re-settle localities, especially with higher elevation, in the Krušné Mountains and strong industrialization and urbanization in the basin areas below the mountains: the Bílina river (36.7), upper and middle parts the Ohře river $(22.4 ; 24.4 ; 24.1)$, the lower Labe river with the Jílovský brook (31.0), northeast of the Krušné Mountains (26.1), the Lužická Nisa river (22.0), the Upper Jizera river (24.2), and also the basins of the eastern part of the Ostrava agglomeration and the adjacent parts of the Beskydy Mountains - the Ostravice (23.0), Moravice (23.8) and Olše (31.1) rivers.

- Significant changes in the structure caused by complete reorganization of the settlement structure and change in land-use due to loss of the importance of the then 
agricultural-forestry production functions. These changes are characterized especially by decrease in the share of AL and its transformation to PGL or the conversion of both to forest areas. This is characteristic especially for the Bečva river in the Vsetín and Rožnov regions (38.2 - the highest CI among the basins observed), the Upper Morava river (34.1).

- Less significant changes in the land-use structure, affected by local and microregional causes in some less significant basins (e.g. construction of water works, important investments into motorways, factory or warehouse complexes, etc.).

- An essential part of basins not named here cannot be classified to any of the types categories above, both according to the type of changes and intensity of structure measured by the size of the areas.

Changes in the nature, intensity and spatial structure of land-use in Czechia that we found point at positive and negative aspects of this process in terms of potential effect on runoff and flood protection.

Positive aspects of long-term development include the decrease in the share of arable land and increase in the share of forest areas. Both these factors are important to strengthen the natural ability of basins to retain and transform runoff during floods. Although the causes, as well as dynamics of the decrease in the share of arable land differ in individual regions, the following fact is important in terms of impact on the runoff process: the highest decrease in the share of arable land occurs in areas with water springs, where the runoff is formed during extreme events. These are marginal basins in the areas of Šumava (the Bohemian Forest), the Krušné Mountains, the Krkonoše Mountains, the Jeseníky Mountains and the Beskydy Mountains, where arable land passes into permanent grassland as a rule. On the contrary, the decrease in the share of arable land in urbanized lowland areas usually does not bring a positive effect because the arable land most frequently passes into even more intensive forms of land-use, especially built-up areas and infrastructure (see increase in the share of remaining areas), which has a negative impact on the runoff process.

The increase in the share of forest areas is apparent virtually within the whole territory of Czechia. This has a positive effect on the runoff process, marking a positive trend, especially when we consider that the most intensive increase in the share of forest areas occurs in mountainous regions, especially in South-Western Bohemia. Headwater areas into which causal rainfall is usually concentrated during floods are decisive for the formation of runoff, especially for the shape and timing of the progress of flood waves. Strengthening the natural retention function of headwater areas is thus an important element of integrated flood protection.

Negative aspects of long-term land-use changes include significant decrease in the share of permanent grassland, and especially the general growth of the share of builtup areas.

Decrease in the share of permanent grassland is apparent in almost the whole Czechia while it represents a significant element both in terms of natural potential for 
runoff retention and transformation, and of erosion protection. Decrease in the share of grassland can be therefore evaluated as a potential risk factor in the evolution, especially considering that in most areas these plots are transformed into more intensively used categories, i.e. agricultural or built-up areas.

The whole Czechia shows an increase in the share of built-up area, i.e. increase in urbanized and industrial areas, even though with different dynamics. This is a critical process affecting runoff. The main characteristics of built-up area are accelerated runoff due to reinforcement of surface and movement of a significant part of surface runoff into the sewerage system, together with a decrease in the transformation effect of the landscape as a whole, both in water spring and floodplain areas. At the same time, the value of property threatened by floods rises, or potential flood damage increases, thus motivating the need of better flood protection. In urban and industrial areas such protection is usually resolved by an increase in capacity, building embankments or modification of water course, i.e. modifications that prompt further runoff acceleration.

The results of the analysis of temporal and spatial land-use changes can be used as an indicator of critical aspects of land-use evolution and as a tool to identify areas where long-term changes in intensity, nature or structure of land-use may have an impact on natural transformation and retention capacity of the landscape. Areas showing high dynamics of changes and unfavourable nature of land-use development need to be subjected to more detailed analyses, and the main motivating forces need to be identified, with subsequent modelling and verification of their effect on runoff during extreme events.

To conclude we deem it necessary to emphasize that this contribution is far from exhaustively using the potential of land-use evolution analysis, it only opens this issue. To make further analyses based on the evolution of partial BTUs a number partial studies should follow, making use of the phenomena indicated here, and studying entire basins in more detail. Other methods (especially quantitative) have to be used, basing the research on geo-ecological foundations. For those who seek to consider this article in the detail of individual basins, we would like to point out that the data necessary for individual CTUs can be obtained at the following freely-accessible web site: http://lucc.ic.cz/.

\section{Acknowledgements}

The presented research was funded by the Joint Research Scheme MSM 0021620831 "Geographical Systems and Risk Processes in Context of Global Changes and European Integration" and by the research project VaV SM/2/57/05 "Long-term changes in fluvial ecosystems in floodplains affected by extreme floods" which is fully appreciated by the authors.

\section{References}

ATKINS, P., IAN SIMMONS, AND B. ROBERTS, PEOPLE (1998): Land and time. An historical introduction to the relations between landscape, culture and environment. Arnold, USA. 
BIČÍK, I., ŠTĚPÁNEK, V. (1994): Post War Changes of the Land Use Structure in Bohemia and Moravia. Case Study Sudetenland. GeoJournal, 32, 3: 253-259.

BIČÍK, I., GÖTZ, A. (1998): Czech Republic. In: Turnock D.: Privatization in Rural Eastern Europe. The Process of Restitution and Restructuring. London: Edw. Elgar Publishing, Studies of Communism in Transition, 93-120.

BIČÍK, I., JELEČEK, V., ŠTĚPÁNEK, V. (2001): Land-Use Changes and their Social Driving Forces in Czechia in the $19^{\text {th }}$ and $20^{\text {th }}$ Centuries. Land Use Policy, 18, 1: 65-73.

BIČÍK, I., CHROMÝ, P., JANČÁK, V., JELEČEK, L., KUPKOVÁ, L., ŠTĚPÁNEK, V., WINKLEROVÁ, J. (2001): Land use/Land Cover Changes in Czechia over the past 150 Years - An Overwiev. In: Y. Himiyama, A. Mather, I. Bičík, E. V. Milanova, eds.: Land Use/Cover Change in Selected Regions in the World. Asahikawa: Institute of Geography, Hokkaido Univ. of Education, Vol. I, Part IV, 29-39.

BIČÍK I., KUPKOVÁ, L. (2002): "Long-term and Transformational Land Use Changes in Czechia", In: Land Use/Cover Change in Selected Regions in the World. Eds. Y. Himiyama, A. Mather, I. Bičík, E. V. Milanova. Vol. II, Issued by IGU SG LUCC. Asahikawa: Institute of Geography, Hokkaido Univ. of Education, 29-39.

BIČÍK, I., (2002): Dynamic land use in the Czech Republic: Data sources, research methods and Compability. In: Land Use Changes in Comparative Perspective, eds.: Y. Himiyama, M. Hwang, and T. Ichinose, New Delhi: Oxford \& IBH Publishing, 21-30.

BIČÍK, I., CHROMÝ, P., JANČÁK, V., JANUீ, H. eds. (2002): Land Use /Land Cover Changes in the Period of Globalization. Proceedings of the IGU-LUCC International Conference Prague 2001. Prague: Charles University in Prague, Faculty of Science, Dept. of Social Geography and Regional Development, 215 s. ISBN 80-86561-04-6

BIČÍK, I., KUPKOVÁ, L., \& ŠTYCH, P. (2003): Development of Land use Structure in the Otava River Basin in 1845-1948-1990 [původní článek]. In: Acta Universitatis Carolinae - Geographica 2003, 38, 2, s. 66-79.

BIČÍK, I., JANČĆK, V. (2004): The Transformation of the Czech Agriculture after 1990. In: Drbohlav, D., Kalvoda, J., Voženílek, V., eds., Czech Geography at the Dawn of the Millenium. Olomouc: Palacký University in Olomouc, 271-291.

BIČÍK, I., JELEČEK, L. (2005): Political Events Factoring into Land-Use Changes in Czechia in the $20^{\text {th }}$ century. In: E. Milanova, Y. Himiyama, I. Bičík, eds., Understanding Land-Use and Land-Cover Change in Global and Regional Context. Enfield (NH), USA, Plymouth, UK: Science Publishers, Inc., 165-186.

BRANDT, J., PRIMDAHL, J., REENBERG, A. (1999): Rural land-use and dynamic forces - analysis of driving forces in space and time. In: Krönert, R. et al., eds.: Land-use changes and their environmental impact in rural areas in Europe. Paris: UNESCO, 81-102.

BÜRGI, M., HERSPERGER, A., M., SCHEEBERGER, N. (2004): Driving Forces of Landscape Change Current and New Directions. Landscape Ecology, 19, 857-868.

Database LUCC Czechia, Charles University in Prague, Faculty of Science, 2001.

DE ROO, A., ODIJK, M., SCHMUCK, G., KOSTER, E., \& LUCIEER, A. (2001): Assessing the effects of land use changes on floods in the Meuse and Oder catchment. Physics and Chemistry of the Earth, Part B: Hydrology, Oceans and Atmosphere, 267-268, 593-599.

DOLEŽAL, F. (2005): Functioning of drainage systems, their usefulness or harmfulness. In: Z. Kulhavý, F. Doležal , M. Soukup (Eds.): Drainage of agricultural lands in the context of cultural landscape (pp. 19-22). Praha: VÚMOP.

GEIST, H. ed. (2006): Our Earth's Changing Land: An Encyclopedia of Land-Use and Cover Change. Vol. 1: A-K, Vol. 2: L-Z. Westport, CT, Greenwood Press, 717 pp.

HABERL, H., BATTERBURY, S., MORAN, E. (2001): Using and shaping the land: a long-term perspective. Land Use Policy, 18, 1: 1-8.

HAIS, M. (2006): Využití metod dálkového průzkumu Země pro hodnocení povodňových událostí. In: J. Langhammer (Ed.), Povodně a změny v krajině. Praha: MŽP a PřF UK, 123-138.

HAMPL, M. et al. (1999): Geography of Societal Transformation in the Czech Republic. UK Praha, 242 pp.

HAMPL, M. (1992): Ecological problems, development of the society and geography, AUC - Geographica, 1: 7-10, Prague, pp. 7-10.

HLADNÝ, J., BLAŽEK, V., DVORÁK, V., \& KUBÁT, J. (1998): Vyhodnocení povodňové situace v červenci 1997. Souhrnná zpráva projektu. Prague: Ministerstvo životního prostředí ČR, Praha, 81 pp. 
HORRITT, M. S. \& BATES, P. D. (2002): Evaluation of 1D and 2D numerical models for predicting river flood inundation. Journal of Hydrology, 2681-4, 87-99.

JELEČEK, L. (1995): Changes in the Production and Techniques in the Agriculture of Bohemia 1870-1945. In: Havinden, M. A., Collins, E. J. T., eds.: Agriculture in the Industrial State. Chapter 6. Reading, UK: Rural History Centre, University of Reading, 126-145.

JELEČEK, L. (1997): Povodně roku 1997 a lesnatost, zatravnění a zornění zasažených oblastí Česka. Geografické rozhledy, 7, 1997/98, č. 3, s. 70-74.

JELEČEK, L. (2002): Historical Development of Society and LUCC in Czechia 1800-2000: Major Societal Driving Forces of Land Use Changes. In: I. Bičík et al., eds.: Land Use/Land Cover Changes in the Period of Globalization. Proceedings of the IGU-LUCC International Conference Prague 2001, Prague, 44-57.

JENSEN, J. R. (2000): Remote Sensing of the Environment. London: Prentice Hall 541 pp.

KLIMENT, Z., MATOUŠKOVÁ, M. (2006): Changes of runoff regime according to human impact on the landscape. Geografie - Sborník ČGS, 111 (3), 292-304.

KRAUSMANN, F., HABERL, H., NIELS S., ERB, K., DARGE, E., GAUBE, V. (2003): Land-use change and socio-economic metabolism in Austria - Part I: Driving forces of land-use change: 1950-1995. Land Use Policy, 20, 1: 1-20.

KROVÁK, F., PÁNKOVÁ, E. \& DOLEŽAL, F. (2004): Vliv lesních ekosystémů na hydrický režim krajiny. (Paper presented at the Aktuality šumavského výzkumu), 37-43.

LAMBIN, E., GEIST, H. (2007): Causes of land-use and land-cover change. The Encyclopedia of Earth: Content, Credibility, Community. In: http://www.eoearth.org/article/Causes_of_land-use_and_landcover_change. Retrieved: Aug 18.

LANGHAMMER, J. (2007): Anthropogenic modifications of streams and floodplain as factors in flood vulnerability. (In: T. Sorensen (Ed.), Progress in Sustainable Rural Development. Montréal, Armidale: Université de Montréal and University of New England, pp. 182-190.

LANGHAMMER, J., VAJSKEBR, V. (2003): Historical Shortening of River Network in the Otava River Basin. Acta Universitatis Carolinae - Geographica, 38 (2), 109-124.

LEGESSE, D., VALLET-COULOMB, C., GASSE, F. (2003): Hydrological response of a catchment to climate and land use changes in Tropical Africa: case study South Central Ethiopia. Journal of Hydrology, 2751 (2), 67-85.

LIPSKÝ, Z. (2001): Present land use changes in the Czech cultural landscape: driving forces and environmental consequences. Moravian Geographical Reports, 9, 2: 2-14.

MAIDMENT, D. R. (1993): Handbook of Hydrology. New York: McGraw-Hill, 1424 pp.

MAREŠ, P., ŠTYCH, P. (2005): Historical Changes in Czech Landscape in 1845-2000 and their Natural and Social Driving Forces Studied at Different Spatial Levels. In: Milanova, E., Himiyama, Y., Bičík, I., eds.: Understanding Land-Use and Land-Cover Change in Global and Regional Context. Science Publishers, chapter 8, 107-134.

MATOUŠKOVÁ, M., KLIMENT, Z. (2006): Změny srážko-odtokových poměrů v pramenných oblastech povodí Otavy. In: J. Langhammer (Ed.): Povodně a změny v krajině MŽP a PřF UK, pp. 317-332.

MILANOVA, E., HIMIYAMA, Y., BIČÍK, I., eds. (2004): Understanding Land-Use and Land-Cover Change in Global and Regional Context. Enfield (NH), USA, Plymouth, UK: Science Publishers, Inc., 350 pp.

MZE. (2008): Czech LPIS MZE.

NAEF, F., SCHERRER, S., WEILER, M. (2002): A process based assessment of the potential to reduce flood runoff by land use change. Journal of Hydrology, 2671 (2), 74-79.

PODHRAZSKA, J. (2002): Influence of changes in land management on watershed retention ability; Vliv změn hospodaření na retenční schopnost povodí. Soil and Water, 2002, (1), 81-88.

ROBINSON, M., DOUGLAS, I., HUGGETT, R., eds. (1997): Companion encyclopedia of geography: The environment and humankind. Routledge, New York, p. 1021.

ROBINSON, M., COGNARD-PLANCQ, A. L., COSANDEY, C., DAVID, J., DURAND, P., FUHRER, H. W., et al. (2003): Studies of the impact of forests on peak flows and baseflows: a European perspective. Forest Ecology and Management, 1861 (3), 85-97.

TRENBERTH, K. E. (1999): Conceptual Framework for Changes of Extremes of the Hydrological Cycle with Climate Change. Climatic Change, 42 (1), 327-339.

TURNER II, B.L., MEYER, W. B. (1994): Changes in Land Use and Land Cover: A Global Perspectives. Cambridge: Cambridge University Press, p. 537. 
TURNER II, BILL L., et al., eds. (1990): The Earth as Transformed by Human Action: Global and Regional Changes in the Biosphere over the Past 300 Years. Cambridge and New York: Cambridge Univ. Press with Clark University.

UHUL. (2008): Forest Management Institute Map Server.

VILÍMEK, V., LANGHAMMER, J. (2003): Assessment of Flood Course and Consequences. Acta Universitatis Carolinae - Geographica, 38 (2), 203-225.

WISKOW, E., VAN DER PLOEG, R. R. (2003): Calculation of drain spacings for optimal rainstorm flood control. Journal of Hydrology, 2721 (4), 163-174.

WORSTER, D. (1990): Transformation of the Earth: Toward an Agroecological Perspective in History. The Journal of American History, 76, 4: 1087-1116.

\section{Résumé}

\section{Hodnocení rizik spojených s dlouhodobými změnami využití ploch v hlavních povodích Česka}

Povodně, které v uplynulých dvou dekádách opakovaně postihly Česko, představovaly ve všech případech výrazné ohrožení života a majetku obyvatel země a přinesly obrovské ztráty v řádu desítek miliard korun. Při hodnocení souvislostí tak mohutných záplav byly jako jedna z příčin extrémních dopadů těchto povodní označovány různé fenomény. Jako takovou prř́činou byly některými autory i veřejností mediálně ovlivněnou označovány úbytek lesních ploch hlavně ve vyšších polohách a celkově vysoká rozoranost území, zvláště ve svažitých polohách, výrazně ovlivňující erozi. Studie, hodnotící změny využití území, které k takovým závěrům mohou opravňovat, však byly zpravidla omezené na lokální nebo regionální studie a nepokrývaly území celé republiky, nebo většinu jejích hlavních povodí.

Článek přináší výsledky výzkumu prostorových aspektů vývoje využití ploch Česka v hlavních povodích v horizontu posledních více než 150 let. Studie vychází z výzkumu dlouhodobých změn využití krajiny na základě rozsáhlé databáze využití ploch Česka (LUCC UK Prague). Databáze zachycuje změny využití ploch v obdobích 1845, 1948, 1990 a 2000 na úrovni jednotlivých katastrálních území Česka. Pro možnost vyhodnocení změn ve vztahu $\mathrm{k}$ odtokovému procesu byly tyto údaje transformovány do ploch povodí IV. řádu. Na těchto základních referenčních plochách byly sledovány základní trendy vývoje jednotlivých kategorií využití ploch, celkový index změny a charakter zjištěných změn vývoje mezi jednotlivými kategoriemi.

Výsledky vyhodnocení přinesly řadu nových zjištění o prostorových aspektech dlouhodobých změn využití území ve vztahu k povodňovému riziku, která vyvracejí řadu stereotypů ve vnímání vývoje krajiny a zároveň upozorňují na rizikové aspekty vývoje.

Pozitivním aspektem vývoje je dlouhodobý pokles výměry orné půdy a nárůst rozlohy zalesněných území. Nárůst rozlohy zalesněného území je dlouhodobý trend a je soustředěn především do pramenných oblastí povodí. Nárůst rozlohy lesní půdy $\mathrm{v}$ těchto oblastech může přispívat ke zvyšování přirozeně retenční schopnosti krajiny a tlumit hydrologické extrémy. Otázkou, kterou charakter dat nemůže postihnout, však zůstává kvalita lesních porostů a vliv lesního hospodaření, které na průběh povodně v konkrétním území mohou mít výrazný vliv.

Pozitivním rysem dlouhodobého vývoje je dále pokles rozlohy orné půdy. Z hlediska možného pozitivního účinku na tlumení odtokových extrémů je důležitý zejména přechod orné půdy na trvalé travní porosty v pramenných oblastech okrajových pohoři ČR, tj. v oblasti, kde dochází $\mathrm{k}$ formování a vývoji klíčových povodňových událostí. Pokles rozlohy zemědělské půdy ale zároveň představuje i možný rizikový prvek vývoje. Jedná se o změny v ní̌inných oblastech, kde zemědělská půda přechází zpravidla na ještě intenzivnější formy využití. Negativním souvisejícím aspektem vývoje je rovněž pokles rozlohy trvalých travních porostů, představujících důležitý prvek z hlediska retenčního a transformačního účinku krajiny, ale i protierozní ochrany.

Za rizikový prvek vývoje je možné považovat rychlý nárůst rozlohy zastavěné plochy. Zastavěné plochy mají nulovou retenční schopnost a silný potenciál pro urychlení odtoku z plochy povodí, což se negativně projevuje na akceleraci dynamiky odtoku při extrémních událostech. Růst zastavěné plochy zároveň vede $\mathrm{k}$ rostoucí hodnotě majetku, vystavenému potenciálnímu ohrožení při povodni. 
V oblastech, kde byla konstatovaná nejvy̌ší dynamika změn a současné nepříznivé trendy vývoje, je třeba provést podrobnější vyhodnocení změn využití krajiny a jejich možného vlivu na povodňové riziko pomocí matematického modelování.

Ivan Bičik

Charles University in Prague Faculty of Science, Department of Social Geography and Regional Development

Albertov 6

12843 Prague 2

Czech Republic

e-mail: bicik@natur.cuni.cz

Jakub Langhammer

Charles University in Prague

Faculty of Science, Department of Physical Geography and Geoecology

Albertov 6

12843 Prague 2

Czech Republic

e-mail:langhamr@natur.cuni.cz

Přemysl Štych, Lucie Kupková

Charles University in Prague

Faculty of Science, Department of Applied Geoinformatics

and Cartography

Albertov 6

12843 Prague 2

Czech Republic

e-mail: stych@natur.cuni.cz

lkupkova@tiscali.cz 